\title{
PAMPAS GRASS CONTROL WITH HALOXYFOP IN CONSERVATION SITES ON DIFFICULT TERRAIN
}

\author{
A.I. POPAY ${ }^{1}$ and S. TIMMINS ${ }^{2}$ \\ ${ }^{1}$ WeedWise, 64 Plunket Terrace, Hamilton \\ ${ }^{2}$ Department of Conservation, PO Box 10-420, Wellington \\ Corresponding author: popay@paradise.net.nz
}

\begin{abstract}
An effective method was sought to control pampas grass (Cortaderia selloana) in conservation sites with difficult terrain. At one such site, the dunes and dune slack communities on Pouto Peninsula, we tested three methods of applying the herbicide haloxyfop from a helicopter: beer keg, weighted nozzle and lance. All three methods gave a similar, high level of control of pampas grass but differed considerably in cost. One year after herbicide application, many of the pampas grass plants in the plots had new shoots, and native plant species had begun to colonise the old pampas clumps. All sprayed plots needed treatment of the regrowth to completely control the pampas grass.
\end{abstract}

Keywords: Cortaderia selloana, haloxyfop, protected areas, sand dunes, wetlands.

\section{INTRODUCTION}

Pampas grass (Cortaderia selloana), a tall, robust grass that can form clumps several metres in diameter, has invaded many open sites of conservation significance throughout New Zealand, particularly in the North Island. At these sites it displaces native species and prevents their regeneration. The Department of Conservation (DOC) wants to control pampas grass at important sites but this is difficult on steep coastal cliff faces, mobile hill slopes, narrow gullies, sand dunes or wetlands. One such site, Pouto Swamp, was chosen to compare the cost-effectiveness of methods of controlling pampas grass in difficult terrain.

Pouto Swamp is a 2000 ha conservation area in a sand dune complex with a mixture of natural wet and drier habitats, near the north head of Kaipara Harbour, Northland. It is notable for two reasons. It has the largest expanse of natural dune and dune slack communities in the Kaipara Ecological Region, and threatened and local plant species are present (Ogle 1997). Pampas grass has invaded much of the area, displacing some native dune and wetland species. The mounds of dead dry foliage in the centre of the pampas grass clumps are only slowly colonised by native plant species.

Our aim was to compare the cost-effectiveness of three methods of applying haloxyfop (Gallant NF), a grass-selective herbicide that does not affect broadleaf species.

\section{METHODS}

Three methods of application of herbicide from a helicopter were used: directed lance, weighted nozzle and beer keg (Wooster 1998). The lance is a handgun fitted with a $1.5 \mathrm{~m}$ long lance, operated by a passenger in a helicopter flying about $5 \mathrm{~m}$ above the pampas, who directs a narrow stream of herbicide directly onto the target plant. The weighted nozzle is a single solid-cone nozzle suspended on a $25 \mathrm{~m}$ chain, entwined with the spray hose. The pilot lowers the nozzle immediately above the plant to be sprayed and activates it. The 50 litre beer keg, with six solid-cone nozzles fitted to a frame at the base of the $\mathrm{keg}$, is slung under the helicopter on a $10 \mathrm{~m}$ strop. Air from a compressor displaces the spray solution through a solenoid valve. The helicopter hovers with the spray unit $1 \mathrm{~m}$ above the pampas. The device, operated by the pilot, releases a fine spray covering a $3 \mathrm{~m}$ 
diameter area and this is carried into the foliage by the vortex from the helicopter rotor. These methods were selected on the basis of a review of pampas grass control methods in New Zealand by Gosling et al. (1999). The haloxyfop was applied at the rate of $500 \mathrm{ml}$ product $/ 100$ litres water, with Uptake adjuvant oil added to the spray mix, also at $500 \mathrm{ml} / 100$ litres.

Preliminary tests measured, for each application method, herbicide flow rate and spray coverage on pampas foliage. Two experiments were established. One compared the effectiveness of the three application methods in killing pampas grass. A second compared approximate application costs over large areas.

In the first experiment, 40 pampas grass plots, each containing 10 discrete pampas grass clumps, were permanently marked and made obvious from the air. Each plot, separated from the next by at least $10 \mathrm{~m}$, was designated at random to receive one of the three treatments or to be left untreated (no herbicide applied). Thus, four such adjacent plots made up 1 of 10 experimental replicates. Five days before spraying each clump was assessed for size, maximum height (excluding flower spikes), percent completeness of the circle of pampas grass foliage, and presence of other plant species within the pampas clumps. Herbicide treatments were applied on 15 November 1999. A Hughes 500 helicopter applied the beer keg treatment and a Squirrel helicopter the lance and weighted nozzle treatments. Ideally, all the treatments within a replicate should have been treated before the next replicate was started, but this proved impractical. Practical constraints also made it impossible to apply the same amount of herbicide to each plot, although amounts applied were assessed. In February and again in November 2000 the clumps were reassessed as above, and the percent desiccation of each clump was visually assessed. Data were analysed as randomised blocks.

The second experiment investigated the time taken to treat large areas of pampasinfested swamp. Each of three areas of between 0.21 and 0.24 ha was treated with the three different application methods. The total time taken to treat each area using each method, including time taken in flying, spraying and re-filling the tanks, was noted. No biological assessments after spraying were made in this experiment.

\section{Flow rate and spray coverage}

\section{RESULTS}

Flow rates for each application method were beer keg: 6 litres/min, weighted nozzle: $8.2 \mathrm{litres} / \mathrm{min}$ and lance: $15.3 \mathrm{litres} / \mathrm{min}$. All three herbicide treatments gave complete coverage of the upper leaf surfaces of the pampas. The weighted nozzle and beer keg gave even distribution of herbicide on the leaf, but the force of the spray jet from the lance blew droplets off the leaf tips and forced herbicide into the leaf bases.

Effects of different application methods

All three herbicide application methods desiccated pampas foliage, resulting in reduced plant height and completeness of the circle of foliage. Any significant differences between the effects of the different application methods were small and fleeting. The change in pampas grass height is given in Figure 1. The height of untreated plants changed only slightly.

Similarly, all herbicide treatments significantly reduced the completeness of live pampas grass foliage encircling the clumps by comparison with untreated pampas grass clumps (Fig. 2). At the February assessment, treatment with the weighted nozzle was significantly more effective than with the lance $(\mathrm{P}<0.05)$; the beer keg treatment was intermediate. At the November assessment, there were no differences $(\mathrm{P}>0.05)$ between the treatments.

All three application methods resulted in similar levels of desiccation of the pampas grass (Fig. 3), with no differences ( $\mathrm{P}>0.05$ ) between them at either assessment.

Many new shoots were apparent on the untreated pampas grass clumps at both the February and November assessments. By the November assessment some new shoots 


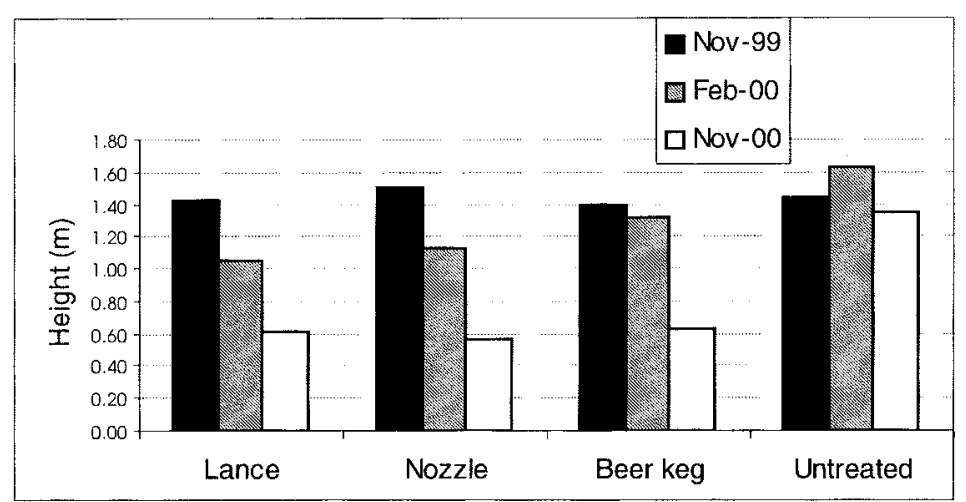

FIGURE 1: Mean pampas plant height before and at two times after herbicide application.

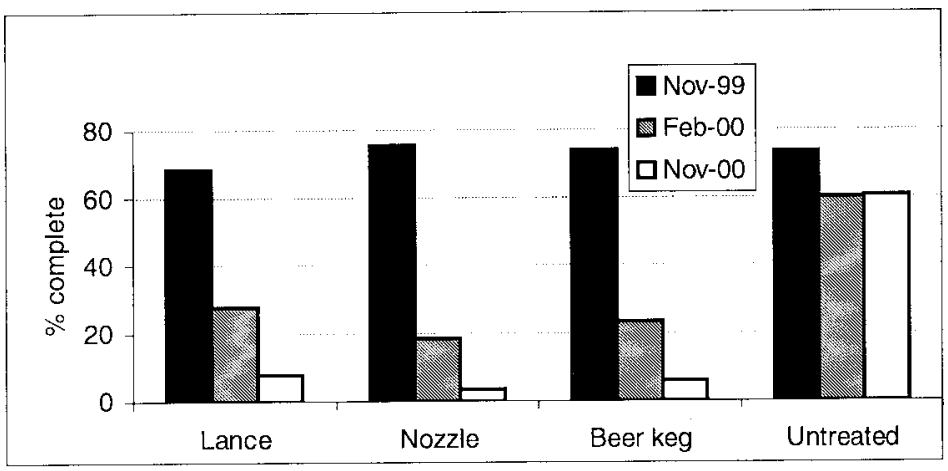

FIGURE 2: Mean pampas clump completeness before the herbicides were applied, and at two times after herbicide application.

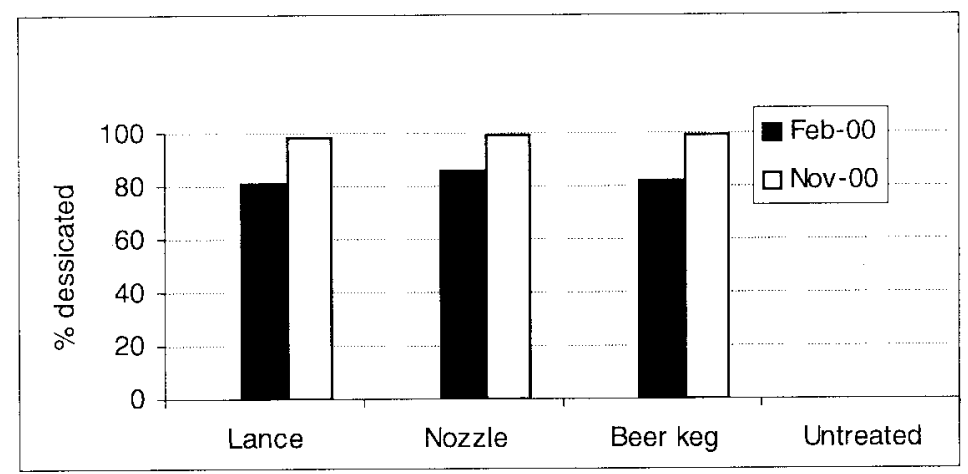

FIGURE 3: Pampas clump desiccation at two times after herbicide application. 
had also appeared from most of the treated pampas grass clumps. There was no difference $(\mathrm{P}>0.05)$ between the treatments (Table 1).

TABLE 1: Number of new shoots/pampas grass clump under different herbicide application methods.

\begin{tabular}{lccc}
\hline & Lance & Weighted nozzle & Beer keg \\
\hline February 2000 & 0.07 & 0.00 & 0.08 \\
November 2000 & 3.37 & 2.39 & 2.68 \\
\hline
\end{tabular}

\section{Large plot application times}

Flying, spraying and refilling times for the three herbicide application treatments are shown in Table 2. The times are the average for the different plots and are extrapolated to 1 ha plots.

TABLE 2: Time (min) to apply each treatment to one hectare.

\begin{tabular}{lllll}
\hline & Flying & Spraying & Refilling & Total \\
\hline Lance & 18.98 & 107.06 & 24.91 & 150.95 \\
Weighted nozzle & 25.59 & 197.9 & 23.69 & 247.17 \\
Beer keg & 49.77 & 118.7 & 65.68 & 234.12 \\
\hline
\end{tabular}

The beer keg method used least herbicide per minute and was used with the smaller Hughes 500 helicopter, but had to be refilled regularly. The lance treatment required the shortest flying and spraying times and the overall time of the operation was much shorter than for the other two treatments. Approximate costs of applying haloxyfop to large plos, baed on the data presented here, are shown in Table 3.

TABLE 3: Costs of applying herbicide (\$/ha) using the three application methods.

\begin{tabular}{|c|c|c|c|}
\hline & Lance & Weighted nozzle & Beer keg \\
\hline haloxyfop + Uptake & 859 & 851 & 373 \\
\hline helicopter time $^{2}$ & 3446 & 5643 & 3512 \\
\hline TOTAL & 4305 & 6494 & 3885 \\
\hline
\end{tabular}

${ }^{1}$ Gallant retail price (Wrightsons, 6 April 2001) \$1896/20 litres; Uptake \$201/20 litres. ${ }^{2}$ Helicopters (at time of spraying): Squirrel \$1370/hour, Hughes $500 \$ 900 /$ hour.

\section{DISCUSSION}

Despite the difficulties of implementing the experimental design, which meant that application methods were confounded with herbicide rate, helicopter type, pilot and time of day, all three application methods gave very good control of the pampas grass clumps initially present. By the time of the November assessment, the pampas grass clumps were being re-colonised by a number of native plant species apparently unaffected by the herbicide. However, new pampas grass shoots had started to emerge on the sites of the old clumps, and these will have to be treated, probably by ground application of haloxyfop.

The beer keg was cheapest of the three methods tested, but the cost of treatment is very dependent on the type of helicopter used. 


\section{ACKNOWLEDGEMENTS}

Thanks to Lisa Forester and Tony McCluggage of Northland Conservancy, Department of Conservation who helped collect the field data. Tony also supervised the spray operation. Jennifer Brown gave advice on the original experimental design and helped with the initial set up of the plots. Trevor James and John Waller, both of AgResearch, helped with trial planning and statistical analysis.

\section{REFERENCES}

Gosling, D. S.; Shaw, W.B.; Beadel, S.M. 1999: Review of control methods for pampas grasses in New Zealand. Science for Conservation 165. Department of Conservation, Wellington. $33 \mathrm{p}$.

Ogle, C.C. 1997: Sand movement and the protection of natural areas on Pouto Peninsula, Northland. Conservation Advisory Scientist notes 145. Department of Conservation, Wellington. $24 \mathrm{p}$.

Wooster, M. 1998: A practical application for a beer keg - spot spraying from a helicopter. Proceedings of New Zealand Biosecurity Institute 48th National Education \& Training Seminar, Working together for success, 13-14 July 1998, Wellington. Pp. $38-42$. 